\title{
Platelets volume indexes and cardiovascular risk factors
}

Thaís Resende Batista ${ }^{1}$

Roberta Carvalho de Figueiredo ${ }^{1}$

(i) Danyelle Romana Alves Rios ${ }^{1}$

1. Dona Lindu Center West Campus, Federal University of São João del-Rei, São João del Rei MG, Brasil

\section{SUMMARY}

Obesity, diabetes and hypertension are risk factors for cardiovascular diseases (CVD) because they promote a state of hypercoagulability. It is known that platelets play an important role in the development of atherosclerosis. Recent studies have evaluated platelet volume indexes (PVIs) in individuals with risk factors for CVD to better understand the platelet mechanisms involved in their development. The IVPs indirectly estimate platelet function and are easily obtained from automated hematology analyzers, which provide platelet counts, mean platelet volume (MPV), platelet distribution width (PDW) and the platelet-large cell ratio (P-LCR). The present study aims to review literature studies that investigated the association between PVIs and obesity, diabetes, and arterial hypertension, in order to evaluate its use as a potential subclinical marker of CVD. Studies have shown promising results for MPV, an index that allows for early detection of platelet activation and may be useful in identifying patients before the onset of CVD development so that preventive strategies can be implemented. The PDW, although evaluated by a smaller number of studies, also showed promising results. However, there is still a long way to go in order for the MPV and PDW to be used in clinical practice, since there is still a need for more epidemiological evidence, establishing reference values, and standardizing the way results are presented.

KEYWORDS: Platelets indexes. Obesity. Diabetes mellitus. Hypertension..

\section{INTRODUCTION}

Cardiovascular diseases (CVD) are represented by a set of diseases that affect blood vessels and the heart. The pathophysiological mechanisms depend on the developing disease'. The coronary artery disease, cerebrovascular accident (CVA), and peripheral arterial disease involve atherosclerosis, a multi-factor disease that promotes accumulation of lipids, inflammatory cells and fibrous elements that are deposited on the walls of arteries and are responsible for the formation of greasy plaques or striae, which usually cause them to become obstructed ${ }^{2}$.
It is known that platelets play an important role in the development of atherosclerosis and thrombi ${ }^{3}$. The platelet volume indexes (PVIs) can directly estimate the platelet function and are easily obtained from more modern automated hematology analyz$\mathrm{ers}^{4}$. The analyzers provide platelet counts, mean platelet volume (MPV), platelet distribution width (PDW), and platelet-large cell ratio (P-LCR). Larger platelets are metabolically and enzymatically more active in comparison to smaller ones because they contain more alpha granules, produce more throm-

DATE OF SUBMISSION: 11-Sep-2017

DATE OF ACCEPTANCE: 25-Sep-2017

CORRESPONDING AUTHOR: Danyelle Rios

Rua Sebastião Gonçalves Coelho, 400

Divinópolis - MG - Brasil - 36307-352 
boxane A2 and feature high expression of adhesive glycoproteins ${ }^{5}$.

Therefore, studies have investigated the association between PVIs and risk factors for CVD, among which are obesity, diabetes, and hypertension, as an attempt to better understand the platelet mechanisms involved in its development ${ }^{1,3,6-9}$. However, the results have been conflicting and despite the relative ease of obtaining these indexes, their use in clinical practice is still limited by the absence of standardization of procedures for measuring and interpreting its results. Thus, the presents study aims to review studies in the literature that investigated the link between PVIs and obesity, diabetes, and hypertension in order to assess its use as a potential subclinical marker of CVD.

\section{PVI AND OBESITY}

Obesity is a chronic metabolic disorder characterized by the excessive accumulation of body fat ${ }^{10}$. According to the World Health Organization (WHO), in order for an individual to be considered obese, they need to present a body mass index (BMI) equal or superior to $30 \mathrm{~kg} / \mathrm{m}^{2}{ }^{11}$. Obesity has been considered an epidemic and is a recognized risk factor for the development of $\mathrm{CVD}^{12}$.

The platelet function can be modulated by metabolism and body weight regulators. The leptin hormone, for example, in heightened in obese individuals and, therefore, contributes to the platelet hyperreactivity ${ }^{13}$. In addition, the platelet activation plays an important role in the development of atherothrombosis, which is a result of the interaction between alterations typical of obesity, such as: insulin resistance, inflammation, oxidative stress, and endothelial dysfunction ${ }^{13}$. In view of this, PVIs have been studied as possible biomarkers for predicting the global risk of CVD in obese individuals ${ }^{14-17}$.

Coban et al. ${ }^{16}$, in a before and after interventional study on with 60 female subjects, observed a mean MPV significantly higher in the group of obese women, in comparison with the non-obese group (8.18 \pm 1.09 vs. $8.01 \pm 0.95 \mathrm{fL}, \mathrm{p}=0.004)$. In the group of obese women, there was a positive correlation between the MPV and BMI $(r=0.43, p=0.017)$ and the reduction of MPV and weight loss ( $r=0.41, p=0.024)$.

Ozkan et al. ${ }^{14}$ analyzed 108 children aged 6-16 years in a case-control study and found that obese children with nonalcoholic fatty liver disease have significantly higher MPV compared to non-obese children (7.44-6.93 fL, $p<0.01)$. Coban et al. ${ }^{15}$, in another case-control study on with 200 subjects, observed a MPV significantly higher in the group of obese individuals, in comparison with the non-obese group (10.3 \pm 1.2 vs. $9.0 \pm 0.8 \mathrm{fL}, \mathrm{p}<0.01)$. In the group of obese individuals, the authors found a positive correlation between MPV and BMI $(p<0.05)$. The researchers also analyzed the platelet count but found no significant difference between the groups.

On the other hand, Montilla et al. ${ }^{17}$, in a cross-sectional study with 307 male individuals, did not observe any significant difference in MPV values between the groups with abdominal obesity (waist circumference $\geq 94 \mathrm{~cm}$ ) and without it (waist circumference $<94 \mathrm{~cm}$ ). However, they observed that those individuals who were in higher terciles of MPV had higher glycemic levels $(5.7 \pm 0.6 \mathrm{mmol} / \mathrm{L}$ vs. $5.99 \pm$ $0.7 \mathrm{mmol} / \mathrm{L}, \mathrm{p}<0.05)$ e lower platelet count $(251 \pm 53$ $/ \mathrm{mm} 3$ vs. $196 \pm 36 / \mathrm{mm} 3, \mathrm{p}<0=0.001)$ in comparison with individuals in lower terciles. They also noticed that the MPV showed a positive correlation, however weak, with prothrombin activity $(r=0.130, p<0.05)$.

Therefore, considering that obesity is a classic risk factor for the development of CVD and that, according to studies, MPV seems to be associated to obesity, it is suggested that such index can be used as a marker for cardiovascular risk.

\section{PVI AND DIABETES}

Diabetes Mellitus (DM) is characterized by a group of metabolic disorders that have in common hyperglycemia as a result of defects in the action/secretion of insulin. The current classification of DM proposed by the World Health Organization (WHO) is based on the etiology of the disease and includes four classes: DM type 1, DM type 2, gestational DM, and other specific types of $\mathrm{DM}^{18}$.

DM type 2 is a worldwide public health problem due to its high morbidity and mortality rates ${ }^{18}$. It is characterized by insulin resistance with gradual and progressive loss of pancreatic beta cell function, with insufficient insulin production and chronic hyperglycemia $^{19}$. Hyperglycemia presents a harmful effect on blood vessels and the risk of mortality due to CVD is reportedly correlated with the concentration of glucose in the blood ${ }^{20}$.

Studies have shown that individuals with DM have larger platelets that release more prothrombot- 
ic factors in comparison with individuals that do not have $\mathrm{DM}^{23,24}$. Patients with type $2 \mathrm{DM}$ have a higher risk of coagulation abnormalities and thromboembolic events ${ }^{25,26}$. Inflammation, oxidative stress, a reduction in the calcium metabolism and in nitric oxide bioavailability, an increase in phosphorylation and glycosylation of cell proteins are all factors responsible for the increase in platelet activation and release of prothrombotic agents ${ }^{22}$. Increased MPV values on individuals with DM in comparison with individuals without DM suggest a compensatory production of larger and more active platelets in the face of a higher activation, which might favor the development of CVD in those individuals. Thus, the use of PVIs as markers of platelet function can be promising to assist in the cardiovascular risk stratification for individuals with DM.

Han et al. ${ }^{27}$, in a cohort study that proposed to assess the association between MPV and the development of cerebrovascular accident (CVA), as well as of peripheral arterial disease (PAD) in individuals with DM found that the group in the higher tercile of MPV ( $\geq 7.9 \mathrm{fL}$ ) presented medium risk of CVA and PAD significantly higher in comparison with the MPV group in the lower tercile ( $\leq 7.3 \mathrm{fL})(29.9 \%$ vs. $2.8 \%$, log-rank: $\mathrm{p}<0.001)$.

Iyidir et al. ${ }^{28}$, in a case-control study develop with pregnant women with (case) and without (control) gestational DM (GDM) found that in the third trimester of pregnancy, MPV was significantly higher among cases in comparison with the control (8.80 \pm 1.0 vs. $8.10 \pm 0.7 \mathrm{fL}, \mathrm{p}=0.002$ ), even after adjustment for confounding factors. There was no significant correlation between glycated hemoglobin (HbA1c) and MPV in the group of pregnant women with GDM. Analysis by ROC curve showed that MPV $\leq 8.4 \mathrm{fL}$ is able to predict GDM with a sensitivity of $63 \%$ and specificity of $66 \%$ (95\% CI: 0.59- 9-0.84).

Demirtas et al. ${ }^{22}$, in a cross-sectional study, demonstrated that the values of MPV and PDW were significantly higher [MPV: 9.20 fL (8.7-9.9) vs. 8.80 fL (8.3-9.3), $\mathrm{p}<0.001$ and PDW: $16.60 \mathrm{fL}$ (15.0-17.8) vs. $15.40 \mathrm{fL}(14.2-16.5), \mathrm{p}<0.001]$ among the patients with DM compared to those who did not have the disease. Among individuals with diabetes, those who had HbA1c $\geq 7 \%$ presented higher MPV $(9.40 \pm 0.9$ vs. $8.90 \pm 0.8 \mathrm{fL})$ and PDW (16.60 fL, 15.3-18 vs. $16.00 \mathrm{fL}$, 15.0-17.0) than those with HbA1c $<7 \%$. A cross-sectional study conducted by Lee et al. ${ }^{23}$ found a positive association $(\mathrm{OR}=2.10, \mathrm{p}=0.012)$ between MPV values and the DM diagnosis, even after adjusting for confounding factors.

Ulutas et al. ${ }^{24}$, also in a cross-sectional study, found significantly higher values of MPV in the group of subjects with DM $(8.30 \pm 1.3 \mathrm{fL})$ compared to the group of individuals without DM $(7.10 \pm 1.0 \mathrm{fL}$; $\mathrm{p}<0.001)$. Among the individuals with DM, the values of MPV were higher for those with HbA1c $>7 \%$ $(8.30 \pm 1.3 \mathrm{fL})$ compared to those with HbA1c $\leq 7 \%$ (7.50 $\pm 1.1 \mathrm{fL} ; \mathrm{p}=0.039)$. MPV presented a positive correlation with HbA1c $(\mathrm{r}=0.39, \mathrm{p}<0.001)$ and with plasma glucose $(\mathrm{r}=0.41, \mathrm{p}<0.001)$, as well as with diabetes duration $(\mathrm{r}=0.22 ; \mathrm{p}=0.02)$.

Finally, Shimodaira et al. ${ }^{29}$, in a cross-sectional study, compared MPV values between subjects without DM and pre-diabetics subjects and observed a significantly higher value in the pre-diabetic group $(\mathrm{p}<0.001)$. Multiple linear regression analyses showed that MPV was independent and positively associated with fasting plasma glucose $(p=0.020$; $\mathrm{p}<0.001)$ not only in pre-diabetic individuals, but also in subjects with normal plasma glucose levels $(\beta=0.006, p<0.05)$.

\section{PVI AND HYPERTENSION}

Arterial hypertension (AH) is a clinical condition characterized by the sustained elevation in pressure levels and is frequently associated with metabolic disorders and target-organ functional/structural alterations ${ }^{30}$. It causes changes in the vascular endothelium and platelets, as well as an increase in plasma levels of prothrombotic substances, which can be related to the development of $\mathrm{CVD}^{31,32}$. Studies have shown that PVIs are increased in patients with AH compared to those without the disease. In this sense, the use of these indexes seems useful for cardiovascular risk stratification and might contribute to preventive and treatment measures for $\mathrm{CVD}^{33,34}$.

Yazici et al. ${ }^{33}$, in a case-control study, evaluated individuals with pre-hypertension (systolic blood pressure: $120-139 \mathrm{mmHg}$ or diastolic blood pressure: 80-89 mmHg) compared to healthy controls, and observed that the MPV values were higher in the first group in comparison to the second $(10.41 \pm 0.93 \mathrm{fL}$ vs. $9.56 \pm 1.04 \mathrm{fL}, \mathrm{p}<0.01)$. There was an association between elevated MPV and pre-hypertension, even after adjusting for confounding factors ( $\mathrm{OR}=0.044,95 \% \mathrm{CI}$ : $0.003 \pm-0.0724, p=0.029)$. In addition, the MPV was correlated with the systolic blood pressure, BMI, and 
insulin resistance in the control group $(\mathrm{r}=0.41, \mathrm{p}<0.02$, $\mathrm{r}=0.37, \mathrm{p}<0.04, \mathrm{r}=0.35, \mathrm{p}<0.05$, respectively).

Coban et al. ${ }^{34}$, in a case-control study, found that MPV was significantly higher in patients with essential hypertension and white coat syndrome than in normotensive individuals $(p<0.00)$, whereas patients with essential hypertension showed higher MPV than those with white coat syndrome $(\mathrm{p}<0.05)$. The platelet count was not different between the groups studied ( $>0.05)$ and MPV was positively correlated with the diastolic pressure in essential hypertension and white coat syndrome groups $(\mathrm{p}<0.05)$.

A cross-sectional study developed by Boos et al. ${ }^{35}$ showed that patients with high-risk AH (HRAH) and malignant AH (MAH) had higher MPV than subjects without these diseases $(7.80 \pm 0.9$ vs. $8.10 \pm 1.0$ vs. $7.40 \pm 0.6 \mathrm{fL}, \mathrm{p}=0.0002$, respectively). PDW was significantly lower among subjects with MAH (5.00 \pm 0.5 vs. $5.40 \pm 0.4 \mathrm{~g} / \mathrm{dL}, \mathrm{p}=0.001)$, with HRAH (5.00 \pm 0.5 vs. $5.30 \pm 0.5 \mathrm{~g} / \mathrm{dL}, \mathrm{p}=0.001)$ compared to individuals without these diseases. In the multivariate regression analysis performed with the hypertensive group (HRAH and MAH), a significant relationship was found between MPV and PDW $(\mathrm{p}<0.0001)$, systolic pressure $(p=0.008)$ and platelet count $(p<0.0001)$.

Yarlioglues et al. ${ }^{36}$, in a cross-sectional study conducted only with men with arterial hypertension, found that MPV positively correlated with systolic and diastolic blood pressure $(\mathrm{r}=0.51, \mathrm{p}<0.001$ and $r=0.55, p<0.001$, respectively). Multiple linear regression analysis identified that levels of MPV were associated with proteinuria severity (coefficient $=0.45$, $\mathrm{p}=0.001$ ), carotid intima-media thickness (coefficient $=0.49, \mathrm{p}=0.001)$, and ventricular mass increase (coefficient $=0.48, \mathrm{p}=0.001$ ).

Erdogan et al. ${ }^{37}$, also in a cross-sectional study, analyzed individuals with false uncontrolled $\mathrm{AH}$, with white coat syndrome (group I), and individuals with true uncontrolled $\mathrm{AH}$, with nocturnal reduction of systolic BP $\geq 10 \%$ (dipper) (group II), and with nocturnal reduction of systolic BP $<10 \%$ (non-dipper) (group III). They observed that platelet counts were significantly lower in group III than in groups I and II $(p<0.0001$ and $p<0.01$, respectively) and was signifi-

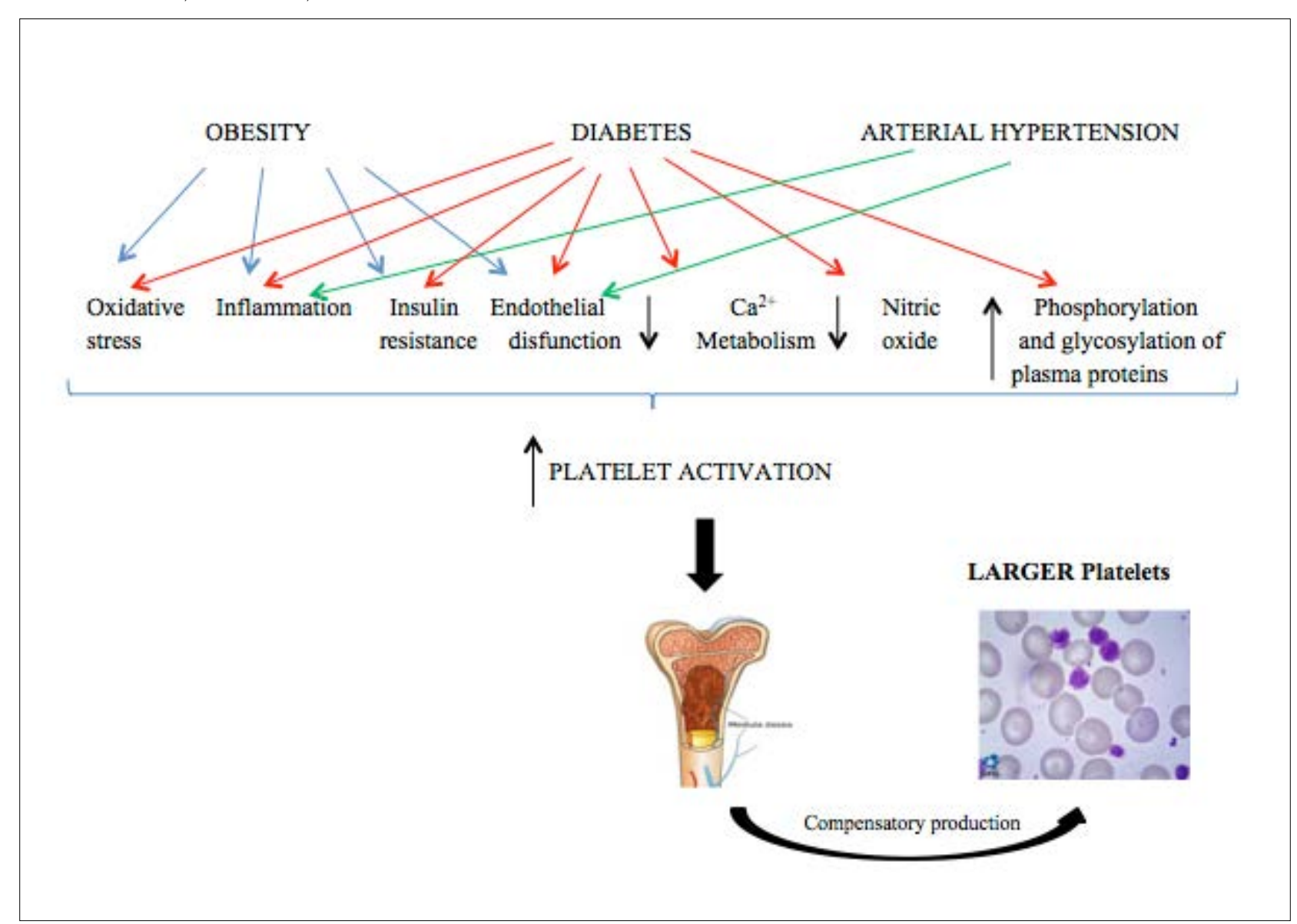


cantly lower in group II than in group I $(\mathrm{p}<0.0001)$. MPV was significantly higher in group III than in groups I and II ( $<<0.0001$ and $p<0.01$, respectively) and was significantly higher in group II than in group I $(\mathrm{p}<0.0001)$.

$\mathrm{AH}$ is responsible for causing damage to the vascular endothelium, promoting platelet adhesion, activation, and aggregation, which causes a great peripheral consumption of platelets ${ }^{31}$. This process is likely the great responsible for inducing a compensatory production of enlarged platelets, which elevate MPV and PDW values in these individuals and consequently, increases the risk of CVD.

\section{FINAL CONSIDERATIONS}

The platelets and their pro-inflammatory and prothrombotic functions play an important role in the development of atherosclerotic plaques and thrombi formation. Thus, seeking to understand these mechanisms, many researchers have been focusing their interest in measuring platelet functions. The studies analyzed here showed that since the launch of the automated hematology analyzers, which release PVIs, MPV has been the most studied index, followed by PDW.

The great majority of studies has demonstrated an increased MPV in obese individuals with DM or AH in comparison with healthy individuals. People with those CVD risk factors present greater platelet activation, which promotes an increased peripheral consumption of platelets, with a consequent compensatory production of platelets that are larger and more reactive by the bone marrow ${ }^{6}$.

A limitation of the analysis of the PVIs refers to the lack of standardization of the anticoagulants used in blood collection, since the use of sodium citrate is recommended for analysis or, in the case of EDTA collection, the analysis should be performed within two hours after collection, as it may cause an increase in platelet volume. In addition, another limitation in the analysis of the PVIs refers to the lack of reference values, which have not yet been established, and also the lack of standardization regarding the methodology used by the hematology analyzers, which can directly interfere in the comparability of the results.

However, even faced with these limitations, a considerable number of studies have demonstrated concordant and promising results for MPV, an index easily obtained by automated hematology analyzers with low costs. Thus, the early detection of platelet activation can be useful in identifying patients with increased thrombotic risk, before the beginning of CVD development, so that preventive strategies can be implemented.

\section{ACKNOWLEDGMENTS}

The authors thank Fapemig, CNPq and UFSJ/ Brazil.

\section{RESUMO}

A obesidade, o diabetes e a hipertensão arterial são fatores de risco para as doenças cardiovasculares (DCV) por promoverem um estado de hipercoagulabilidade. É sabido que as plaquetas desempenham um importante papel no desenvolvimento da aterosclerose. Diante disso, estudos recentes têm avaliado os índices de volumes plaquetários (IVPs) em indivíduos com fatores de risco para DCV, para melhor se entenderem os mecanismos plaquetários envolvidos no seu desenvolvimento. Os IVPs estimam indiretamente a função plaquetária e são facilmente obtidos a partir de analisadores hematológicos automáticos, que fornecem contagens de plaquetas, volume médio de plaquetas (VPM), largura de distribuição de plaquetas (PDW) e a proporção de plaquetas grandes (P-LCR). O presente trabalho tem por objetivo revisar na literatura estudos que investigaram a associação entre os IVPs e obesidade, diabetes e hipertensão arterial, a fim de avaliar o seu uso como potencial marcador subclínico das DCV. Estudos demonstraram resultados promissores quanto ao VPM, um índice que permite uma deteç̧ão precoce da ativação de plaquetas e que pode ser útil na identificação de pacientes antes do início do desenvolvimento de DCV, de tal forma que estratégias preventivas possam ser implantadas. O PDW, embora tenha sido avaliado por um número menor de estudos, também demonstrou resultados promissores. Entretanto, ainda existe um longo caminho a se percorrer para que o VPM e o PDW sejam utilizados na prática clínica, pois ainda são necessárias mais evidências epidemiológicas, o estabelecimento de valores de referência e a padronização da forma de expressar os resultados.

PALAVRAS-CHAVE: Índices de volume plaquetários. Obesidade. Diabetes mellitus. Hipertensão. 


\section{REFERENCES}

1. World Health Organization, World Heart Federation, World Stroke Organization. Global Atlas on Cardiovascular Disease Prevention and Control. Mendis S, Puska P, Norrving B, eds. Geneva: World Health Organization; 2011.

2. Gottlieb MGV, Bonardi G, Moriguchi EH. Physiopathology and inflammatory aspects of atherosclerosis. Scientia Médica. 2005;15(3):203-7.

3. Kaplan ZS, Jackson SP. The role of platelets in atherothrombosis. Hematology Am Soc Hematol Educ Program. 2011;2011:51-61.

4. Brummitt DR, Barker HF. The determination of a reference range for new platelet parameters produced by the Bayer ADVIA 120 full blood count analyser. Clin Lab Haematol. 2000;22(2):103-7.

5. Martin JF, Kristensen SD, Mathur A, Grove EL, Choudry FA. The causal role of megakaryocyte-platelet hyperactivity in acute coronary syndromes. Nat Rev Cardiol. 2012;9(11):658-70.

6. Lotufo PA. O escore de risco de Framingham para doenças cardiovasculares. Rev Med (São Paulo). 2008;87(4):232-7.

7. Sansanayudh N, Anothaisintaweet, Muntham D, McEvoy M, Attia I, Thakkinstian A. Mean platelet volume and coronary artery disease: a systematic review and meta-analysis. Int | Cardiol. 2014;175(3):433-40.

8. Kario K, Matsuo T, Nakao K. Cigarette-smoking increases the mean platelet volume in elderly patients with risk factors for atherosclerosis. Clin Lab Haematol. 1992;14(4):281-7.

9. Zaccardi F, Rocca B, Pitocco D, Tanese L, Rizzi A, Ghirlanda G. Platelet mean volume, distribution width, and count in type 2 diabetes, impaired fasting glucose, and metabolic syndrome: a meta-analysis. Diabetes $\mathrm{Me}-$ tab Res Rev. 2015;31(4):402-10.

10. Klein S, Burke LE, Bray GA, Blair S, Allison DB, Pi-Sunyer X, et al; American Heart Association Council on Nutrition, Physical Activity, and Metabolism. Clinical implications of obesity with specific focus on cardiovascular disease: a statement for professionals from the American Heart Association Council on Nutrition, Physical Activity, and Metabolism: endorsed by the American College of Cardiology Foundation. Circulation. 2004;110(18):2952-67.

11. Sociedade Brasileira de Endocrinologia e Metabologia. Obesidade. [cited 2017 Jan 28]. Available from: http://www.endocrino.org.br/obesidade/

12. Morange PE, Alessi MC. Thrombosis in central obesity and metabolic syndrome: mechanisms and epidemiology. Thromb Haemost. 2013;110(4):669-80.

13. Santilli F, Vazzana N, Liani R, Guagnano MT, Davì G. Platelet activation in obesity and metabolic syndrome. Obes Rev. 2012;13(1):27-42.

14. Özkan EA, Khosroshahi HE, Serin HI, Özdemir ZT, Kılıç M, Ekim M, et al. The evaluation of carotid intima-media thickness and mean platelet volume values and correlation with cardiac functions in obese children. Int J Clin Exp Med. 2015;8(12):22557-63.

15. Coban E, Ozdogan M, Yazicioglu G, Akcit F. The mean platelet volume in patients with obesity. Int J Clin Pract. 2005;59(8):981-2.

16. Coban E, Yilmaz A, Sari R. The effect of weight loss on the mean platelet volume in obese patients. Platelets. 2007;18(3):212-6.

17. Montilla M, Santi MJ, Carrozas MA, Ruiz FA. Biomarkers of the prothrombotic state in abdominal obesity. Nutr Hosp. 2015;31(3):1059-66.

18. Sociedade Brasileira de Diabetes. Diretrizes da Sociedade Brasileira de Diabetes, 2015-2016. [cited 2017 Feb 04]. Available from: http://www.diabetes.org.br/profissionais/images/pdf/DIRETRIZES-SBD-2015-2016.pdf

19. Beckman JA, Creager MA, Libby P. Diabetes and atherosclerosis: epidemiology, pathophysiology, and management. JAMA. 2002;287(19):2570-81.

20. Danaei G, Lawes CM, Vander Hoorn S, Murray C), Ezzati M. Global and regional mortality from ischaemic heart disease and stroke attributable to higher-than-optimum blood glucose concentration: comparative risk assessment. Lancet. 2006;368(9548):1651-9.

21. Temelkova-Kurktschiev TS, Koehler C, Henkel E, Leonhardt W, Fuecker K, Hanefeld M. Postchallenge plasma glucose and glycemic spikes are more strongly associated with atherosclerosis than fasting glucose or $\mathrm{HbA1c}$ level. Diabetes Care. 2000;23(12):1830-4.

22. Demirtas L, Degirmenci $H$, Akbas EM, Ozcicek A, Timuroglu A, Gure A, et al. Association of hematological indicies with diabetes, impaired glucose regulation and microvascular complications of diabetes. Int J Clin Exp Med. 2015;8(7):11420-7.

23. Lee EY, Kima SJ, Song YJ, Choi SJ, Song J. Immature platelet fraction in diabetes mellitus and metabolic syndrome. Thromb Res. 2013;132(6):692-5.

24. Ulutas KT, Dokuyucu R, Sefil F, Yengil E, Sumbu AT, Rizaoglu H, et al. Evaluation of mean platelet volume in patients with type 2 diabetes mellitus and blood glucose regulation: a marker for atherosclerosis? Int J Clin Exp Med. 2014;7(4):955-61.

25. Kim JH, Bae HY, Kim SY. Response: clinical marker of platelet hyperreactivity in diabetes mellitus (diabetes metab j 2013;37:423-8). Diabetes Metab |. 2014;38(2):160-1.

26. Suslova TE, Sitozhevskii AV, Ogurkova ON, Kravchenko ES, Kologrivova IV, Anfinogenova Y; et al. Platelet hemostasis in patients with metabolic syndrome and type 2 diabetes mellitus: cGMP-and NO-dependent mechanisms in the insulin-mediated platelet aggregation. Front Physiol. 2014:5:501.

27. Han JY, Choi DH, Choi SW, Kim BB, Ki YJ, Chung JW, et al. Stroke or coronary artery disease prediction from mean platelet volume in patients with type 2 diabetes mellitus. Platelets. 2013;24(5):401-6.

28. Iyidir OT, Degertekin CK, Yilmaz BA, Toruner FB, Akturk M, Arslan M. Elevated mean platelet volume is associated with gestational diabetes mellitus. Gynecol Endocrinol. 2014;30(9):640-3.

29. Shimodaira M, Niwa T, Nakajima K, Kobayashi M, Hanyu N, Nakayama $\mathrm{T}$. Correlation between mean platelet volume and fasting plasma glucose levels in prediabetic and normoglycemic individuals. Cardiovasc Diabetol. 2013;12:14

30. Malachias MVB, Souza WKSB, Plavnik FL, Rodrigues CIS, Brandão AA, Neves MFT, et al. 7a Diretriz Brasileira de Hipertensão Arterial. Arq Bras Cardiol. 2016;107(3 supl.3):1-83.

31. Islim IF, Bareford D, Ebanks M, Beevers DG. The role of platelets in essential hypertension. Blood Press. 1995;4(4):199-214.

32. Lip GY. Target organ damage and the prothrombotic state in hypertension. Hypertension. 2000;36(6):975-7.

33. Yazici M, Kaya A, Kaya Y, Albayrak S, Cinemre H, Ozhan H. Lifestyle modification decreases the mean platelet volume in prehypertensive patients. Platelets. 2009;20(1):58-63.

34. Coban E, Yazicioglu G, Berkant Avci A, Akcit F. The mean platelet volume in patients with essential and white coat hypertension. Platelets. 2005; 16(7):435-8.

35. Boos C), Beevers GD, Lip GY. Assessment of platelet activation indices using the ADVIATM 120 amongst 'high-risk' patients with hypertension. Ann Med. 2007;39(1):72-8

36. Yarlioglues M, Kaya MG, Ardic I, Dogdu O, Kasapkara HA, Gunturk E, et al. Relationship between mean platelet volume levels and subclinical target organ damage in newly diagnosed hypertensive patients. Blood Press. 2011;20(2):92-7.

37. Erdogan D, Icli A, Aksoy F, Akcay S, Ozaydin M, Ersoy I, et al. Relationships of different blood pressure categories to indices of inflammation and platelet activity in sustained hypertensive patients with uncontrolled office blood pressure. Chronobiol Int. 2013;30(8):973-80. 